DOI: $10.17951 / \operatorname{lrp} .2019 .38 .1 \cdot 161-176$

\author{
Pawee Trzos \\ Wydział Pedagogiki, Uniwersytet Kazimierza Wielkiego w Bydgoszczy \\ ORCID https://orcid.org/0000-0002-9015-4665
}

\title{
KREATYWNOŚĆ W MYŚLENIU MUZYCZNYM JAKO PRZEDMIOT BADAŃ MUZYCZNO-EDUKACYJNYCH STUDENTÓW PEDAGOGIKI WCZESNOSZKOLNEJ
}

\begin{abstract}
Streszczenie: W tekście zwrócono uwagę na wybrane kierunki badań podejmowanych przez studentów pedagogiki wczesnoszkolnej nad warunkami rozwijania kreatywnego myślenia w muzyce. Taką kreatywność analizuje się w kontekście rozwoju audiacji, co w świetle teorii uczenia się muzyki E.E. Gordona określane jest jako jeden z ważniejszych tropów w realizacji procesu kształcenia muzycznego. Dotyczy to różnych form aktywności muzycznej i wpisuje się w zadania przygotowania dziecka do aktywnego uczestnictwa w kulturze muzycznej. Zawężenie refleksji na wczesnoszkolnym wieku uczniów jest konsekwencją poglądów, iż w tym okresie rozwoju bardzo ważny jest dynamiczny program rozwijania myślenia w muzyce.
\end{abstract}

Słowa kluczowe: audiacja, edukacja muzyczna, kreatywne myślenia w muzyce, dziecko

\section{WPROWADZENIE}

Podstawowe zarzuty kierowane pod adresem procesów edukacji muzycznej dotyczą między innymi celu, jaki wyznaczać powinna współczesna szkoła. Pomijając istotny wychowawczy i kulturowy wymiar edukacji muzycznej (Konaszkiewicz $2012 \mathrm{i}$ in.; Grusiewicz 2015, s. 331-335) uwagę coraz częściej koncentruje się na potrzebie wspierania kreatywności i innowacyjności w procesie kształcenia. Programy kształcenia muzycznego (zarówno w przedszkolu, klasach wczesnoszkolnych oraz nauczaniu blokowym) są wciąż zorientowane głównie na odtwórczość i utrwalanie logiki opartej na nauczaniu teorii. Zarzuty, iż brakuje programów realnie rozwijających myślenie twórcze, a w ślad za tym - improwizacyjne, są bardzo często powtarzane. Ważne myślenie konwergencyjne musi być uzupełniane o dyspozycje wynikające 
z myślenia dywergencyjnego, twórczego. Trudno jednak mówić o rozwijaniu twórczego myślenia w muzyce, gdy dominuje behawioryzm, instruktywizm, algorytm lub tzw. „chodzenie po śladzie” (Kojs 2000; Waloszek 2008, s. 37-43; Weiner 2013, s. 31-32). Potrzebne jest rozwijanie myślenia heurystycznego, co w kształceniu muzycznym zdaje się gwarantować rozwój audiacji (Zwolińska 2012, s. 97). Przyjmując analizę kreatywności w rozwijaniu twórczego poziomu audiacji, można założyć, iż chodzi w niej o „proces” przetwarzania zinternalizowanych doświadczeń i wcześniej uformowanych wyobrażeń w nową strukturę specyficznej wyobraźni muzycznej traktowanej ,jako twórczą i konstruktywną" (Reber 1985, s. 345; Zwolińska 2012, s. 46-48; 2016, s. 90). Stąd w artykule tym przedstawiono główne (i wybrane) ujęcia przedmiotu badań nad rozwijaniem kreatywnego myślenia muzycznego, czego zapleczem teoretycznym jest teoria uczenia się muzyki EE. Gordona.

\section{WCZESNOSZKOLNA EDUKACJA MUZYCZNA WOBEC POTRZEB BADAŃ}

Rodzice i nauczyciele wczesnej edukacji muszą być świadomi odpowiedzialności, z jaką wiąże się wczesne utrzymanie potencjału dziecka do nauki muzyki. Zadania rozwijania konkretnych predyspozycji dziecięcego doświadczania znaczeń muzyki wymagają również systematycznej diagnozy tego dynamicznego potencjału. Można sądzić, iż prawidłowy rozwój zdolności audiacyjnych będzie możliwy, pod warunkiem dokonywania istotnych zmian w procesie kształcenia muzycznego już od pierwszych chwil życia dziecka. Rola rodziców - jako pierwszych nauczycieli - jest nie do przecenienia. Znane poglądy badaczy na ten temat podkreślają znaczenie realizacji pierwszych etapów edukacji (Bonna 2006; Gordon 2016; Kołodziejski 2014, s. 149-151; Kamza 2014, s. 23-29; Murawska 2014, s. 25-30; Weiner 2010). Program kształcenia muzycznego nie może opierać się na oddziaływaniach reaktywnych, behawioralnych, ale rozwijać umiejętności eksperymentowania, dialogowania, tworzenia, improwizowania poprzez doświadczanie wielu i różnorodnych zarazem problemów w muzyce.

Problemy te, od kilku lat, definiują - jako przedmiot badań własnych - pracownicy i studenci jedynej w Polsce specjalności kształcącej nauczycieli/specjalistów wczesnoszkolnego nauczania muzyki w oparciu o audiacyjny model kształcenia. W artykule tym refleksję zawężono jedynie do aspektu wybranych badań studenckich nad zmiennymi cechy kreatywnego myślenia w muzyce ${ }^{1}$. Stymulowanie

${ }^{1}$ Zmiennymi, o których mowa wydają się być głównie (ale z pewności nie tylko) te cechy kreatywnego myślenia w muzyce, które dotyczą rozwoju audiacji (w tym pamięci i uwagi muzycznej) w konkretnych typach i etapach aktywności muzycznej. Poziom umiejętności dziecka 
aktywności badawczej studentów (zob. też Trzos 2014a) w obszarze wczesnoszkolnej edukacji muzycznej wymaga przyjęcia konkretnych założeń teoretycznych. Podstawowym (choć nie jedynym) zapleczem teoretycznym jest poznawcza teoria rozwoju audiacji, jako kluczowego warunku rozwijania kreatywnego myślenia w muzyce. Przyjęte założenia oscylują wokół rozwojowego kontinuum od predyspozji dziecka do jego osiągnięć muzycznych, przy czym edukacyjny walor takiej analizy osadza się także na innych (ważnych) rekomendacjach wskazujących istotny kierunek wywoływania zmiany (Fish 1996; Bee 1998; Filipiak, Lemańska-Lewandowska 2015; Filipiak, Lemańska-Lewandowska, Szymczak 2015; Kołodziejski, Trzos 2013; Zwolińska 2016):

- założenia dotyczące pojęcia „uczenia się" i „uczenia się muzyki”,

- założenia dotyczące tworzenia (nie)wiedzy i konstruowania feedbacku rozwijania kreatywności myślenia w muzyce,

- założenia związane z kategoriami tworzenia muzyki,

- założenia w związku z postrzeganiem dziecka nie tyle jako odbiorcy/konsumenta kultury muzycznej, ale twórcy/demiurga/konstruktora,

- założenia dotyczące wymiany udziałów dziecka i dorosłego (nauczyciela/ rodzica) w sytuacjach edukacyjnych.

Można sądzić, iż wczesnoszkolna edukacja muzyczna będzie pełnić funkcje rozwojowe, jeśli rzeczywiście przyjęte założenia i ich odpowiednie realizacje będą spójne i konsekwentne. Stąd główne zadania kreatywnej edukacji muzycznej jako przedmiotu badań oscylują wokół dodatkowych założeń, iż:

- rozwój myślenia muzycznego (zwłaszcza opartego na heurystykach) jest konieczny do prawidłowego dialogowania w typach słuchania, śpiewania, grania na instrumentach, tworzenia i improwizowania, także $\mathrm{w}$ formach ruchowych,

- rozwijanie wrodzonych predyspozycji i zdolności muzycznych umożliwia utrzymanie i rozbudzanie naturalnej wrażliwości dziecięcej w muzyce i „myślenia pytaniami” wobec świata znaczeń, dźwięku i symboli muzycznych (choćby na poziomie skojarzeń graficznych w nauce notacji),

- rozwijanie poczucia samokontroli i wyjścia poza naturalny egocentryzm dziecka w doświadczaniu muzyki jest konieczne do rozwijania muzycznej wrażliwości i twórczej ekspresji,

- kształtowanie dziecięcych postaw opartych na krytycznym opisie doświadczeń w muzyce powinno być łączone z inicjowaniem/projektowaniem sytu-

\footnotetext{
w tych obszarach „muzykowania” może być nie tylko przedmiotem diagnozy danego poziomu sprawności muzycznej dziecka (wbrew częstym uproszczeniom), ale świadczyć o wskaźnikach nabywania dojrzałości przetwarzania przez dziecko treści muzycznej.
} 
acji wspierania dziecięcej autonomii, wrażliwości na różnorodność tonalno-

-rytmiczną, twórczości, dialogowania muzyką oraz myślenia generatywnego.

Wiele zadań jest rozpoczętych i wymaga długoletniego sprawdzania. Jednak warto odnieść sie do wybranych komunikatów, które już dziś wielokrotnie owocują stymulowaniem praktyki muzyczno-edukacyjnej w tym obszarze edukacji muzycznej dziecka.

\section{SPECYFIKA PODEJMOWANYCH BADAŃ STUDENCKICH}

Podejmowane przez studentów kierunku pedagogika wczesnoszkolna badania nad rozwijaniem kreatywności w myśleniu muzycznym mieszczą się w ramach systematycznego ruchu naukowego. Obejmuje on między innymi:

- badania w dydaktyce (seminarium dyplomowe i magisterskie),

- badania i aplikacje (zadania badawczo-rozwojowe zespołów studenckich realizowane w ramach grantów zewnętrznych) oraz

- udział w pracach tworzącego się Laboratorium Rozwoju Kreatywności (LRK) przy Katedrze Pedagogiki Muzyki UKW w Bydgoszczy.

Prezentowane doniesienia pochodzą z okresu 2012-2016 i dotyczą problemów analizy naturalnych warunków kreatywnego rozwoju muzycznego dziecka. Należą do nich dwa wymiary wynikające ze specyfiki zdolności muzycznych dziecka, tj. wymiar tonalny i rytmiczno-metryczny. Inne pole problemowe wyznaczatrudność wyrażona w pytaniach o naturalny rodzaj preferencji muzycznych dziecka w zakresie myślenia brzmieniem instrumentów muzycznych. To bardzo ważny, jak wskazano wcześniej (Gordon 1984; Trzos 2009; Zwolińska 2011, s. 248; 2012, s. 88-92), aspekt projektowania sytuacji dydaktycznych w muzyce. Rozpoznanie bowiem predyspozycji dziecka w tym zakresie dotyczy nie tylko odtwórczego, ale przede wszystkim twórczego wymiaru osiągnięć edukacyjnych w wykonawstwie instrumentalnym, które za Gordonem można określić jako „zewnętrzną rzeczywistość wewnętrznego potencjałuw muzyce”. Chodzi o poznanie możliwości dziecka w zakresie rozwoju kreatywnego myślenia rzeczywistością brzmieniową w muzyce, a w ślad za tym wspierania rozwoju dziecięcej internalizacji „instrumentu wewnętrznego"(Zwolińska 2011, s. 248). Głównymi metodami badań jest testowanie, a z grup metod sondażu: obserwacja ilościowa i wywiad ilościowy.

Badania prowadzone są w Katedrze Pedagogiki Muzyki w Uniwersytecie Kazimierza Wielkiego w Bydgoszczy. Partnerem zewnętrznym jest Fundacja Kreatywnej Edukacji, która jako jedyna w Polsce posiada udokumentowany dorobek w praktycznej organizacji procesu kształcenia opartego na audiacyjnym modelu edukacji muzycznej. Terenem badań były dodatkowo wybrane szkoły podstawowe oraz ośrodek nieformalnego ruchu orkiestrowego MUZA. 


\section{MUZYCZNA KREATYWNOŚĆ \\ W KONTEKŚCIE WYNIKÓW BADAŃ NAD TONALNO-RYTMICZNYM WYMIAREM DZIECIĘCEGO AUDIOWANIA}

W działaniach muzycznych trzeba analizować treść i kontekst muzyki. Jeśli chodzi o treść to dziecko buduje tzw. słowniki muzyczne, które podobnie jak w nauce mowy, służą nabywaniu słownictwa potrzebnego do organizacji i rozumienia treści wypowiedzi językowych (w przypadku muzyki to będzie wypowiedź muzyczna jako wypowiedź quasi językowa). Działania muzyczne dziecka zawsze sprowadzają się do operacjonalizowania nabytej treści muzycznej kojarzonej z nowymi zdarzeniami i w ten sposób wykonywaniem (wy)uczonych motywów tonalnych i rytmicznych. Natomiast kontekst działań muzycznych, analogicznie do składni w języku, jest reprezentowany przez tonalność i metrum (Zwolińska 2011, s. 34). Działania muzyczne dziecka prowadzą do nabywania gotowości rozumienia wzorów tonalnych i rytmicznych (jako konkretnej treści muzycznej) w odniesieniu do kontekstu tonalno-metrycznego (jako konkretnej skali czy metrum). Takie doświadczenia prowadzą do ukształtowania świadomego i kreatywnego „umysłu muzycznego" (Zwolińska 2014, s. 155; 2016, s. 110-129). Proces ten jednak zaczyna się już w okresie wczesnodziecięcym, w którym oddziaływanie nauczycieli, a przede wszystkim rodziców ma charakter nieformalnego kierowania. To uzasadnia wciąż zainteresowanie wiedzą i praktycznymi kompetencjami rodziców i nauczycieli do organizacji działań muzycznych w tym bardzo ważnym okresie rozwoju dziecka (Trzos 2014b, 2016).

W badaniach samooceny rodziców i nauczycieli dotyczącej ich wiedzy i kompetencji w organizowaniu działań na nieformalnym etapie edukacji muzycznej dziecka (Trzos 2014b, s. 127-141) odniesiono się do innych analiz wynikających z badań Kamili Niśkiewicz nad możliwością praktycznego kształtowania umiejętności audiacyjnych w dwóch podstawowych wymiarach działań, tj. tonalnym i rytmicznym (Niśkiewicz 2013). Znaczenie kompetencji nauczycieli i rodziców (muzycznych, pedagogicznych: instrumentalno-technicznych, a także dialogowych, komunikacyjnych) podkreśla założenie E.E. Gordona, że muzyki i jej znaczeń (treści i kontekstu) dziecko uczy się podobnie jak mowy. Rola powtórzeń i imitacji w nabywaniu struktur tonalno-rytmicznych języka muzycznego sprawia, że znaczenia nabierają nawykowo utrwalane postawy i zachowania muzyczne dorosłych osób. O konieczności licznych i prawidłowych powtórzeń właściwych wzorów muzycznych zachowań wyraźnie pisze E.E. Gordon. Dlatego też wpływ na różnicę w wykonaniu przez dzieci struktur tonalnych i rytmicznych ma, obok prawidłowości, także częstotliwość realizacji konkretnych rozwiązań w ramach aktywnego różnicowania w muzyce. To podstawowy element przygotowania 
dziecka do umiejętności dialogowania i wnioskowania w kreowaniu nowych jakości (wypowiedzi) muzycznych. Prawidłowość i częstotliwość tę ujawniły wyniki powyższych badań (Niśkiewicz 2013).

W analizie działań muzycznych dzieci odniesiono się do kryteriów, które są możliwe do stosowania także $\mathrm{w}$ praktyce umuzykalniania dzieci na nieformalnym etapie kierowania muzycznego. Uznano zatem, za E.E. Gordonem, że podstawowymi dyspozycjami, które są naturalne w tym okresie rozwoju muzycznego dziecka jest zdolność postrzegania struktur melodii i rytmu jako całości i szczegółów wykonawczych (Niśkiewicz 2013). Konsekwencją przyjęcia takiego stanowiska były zastosowane w badaniach podstawowe kryteria tonalnej i rytmicznej reprezentacji pojęć muzycznych na etapie różnicowania w muzyce (Gordon 1999, s. 183-280; 2016; zob. też: Gordon i in. 1993; Gordon, Woods 1999).Przyjęciu sprawdzanych w toku badań kryteriów oceny kreatywnych działań muzycznych dzieci przyświecały wnioski E.A. Zwolińskiej o wewnętrzno-zewnętrznej specyfice dziecięcego uczenia się muzyki. Analiza tych dwóch płaszczyzn działań w muzyce (znaczeniowej wewnętrznej i fizycznej zewnętrznej) pomaga zrozumieć, w jaki sposób odbywa się dziecięce poznawanie i różnicowanie (w tym syntetyzowanie) treści muzycznej (Zwolińska 2011, s. 170-171). Stąd, ustanawiając kryteria analizy działań muzycznych dzieci (w większości o charakterze wokalnym), uznano za E.A. Zwolińską, że dzieci naturalnie rozwijają dwie płaszczyzny działań muzycznych: znaczeniową (treść muzyczna postrzegana jest jako całość) i fizyczną (dzieci uczą się fragmentów muzyki, które prowadzą do opanowania całości) (Zwolińska 2011, s. 170).

Analizując uzyskane wyniki oceny wykonań wokalnych² ${ }^{2}$, można było zauważyć, że najwyższe wyniki uzyskano w kryteriach rytmicznych. Trudniejsze okazały się zadania odnoszone do tonalnego, melodycznego kontekstu działań, z których tylko poczucie „dźwięku centralnego"3 spełniało wymogi oceny umiarkowanej i dobrej. To bardzo ważne spostrzeżenie. Pozwala się odnieść do wyników innych badań (Leman 2014; Trzos 2014b, s. 127-141). Okazuje się bowiem, że wyraźnie większe trudności sprawiają zadania opierające się nawet na odtwórczym śpiewie i tonalno-harmonicznym kontekście odtwórczgo wokalnego muzykowania, niż wykonywanie struktur rytmicznych (por. też Leman 2014). To ważna implikacja

2 Analiza działań polegała na przeprowadzeniu dwuetapowego sprawdzianu muzycznego, z wykorzystaniem treści muzycznej (piosenka, utwór do tańca, przykład muzyczny). Aktywność dzieci była obserwowana, a jej rezultaty przełożone na ilościowe wskaźniki w skali numerycznej 1-6, zgodnie z obowiązującym szkolnym systemem oceniania. Obserwacji i ustalenia ilościowych ocen odrębnie dokonywał nauczyciel prowadzący oraz prowadząca badanie studentka (Niśkiewicz 2013).

${ }^{3} \mathrm{~W}$ tonalności dźwiękiem centralnym jest ostatni dźwięk szeregu diatonicznego, a w metrum funkcję centralną pełni makrobit (zob. Gordon 1999, s. 508). 
dla doskonalenia studentów oraz osób zajmujących się kierowaniem muzycznym dzieci. Od rodziców i nauczycieli wczesnej edukacji zależeć będzie realna sprawność dziecięcego muzykowania i pełnego rozumienia muzyki. Warto na to zwracać uwagę w programach akademickiego przygotowania nauczycieli wczesnej edukacji i alternatywnych formach kursów/szkoleń dla rodziców (Trzos 2014b, s. 127-141).

Szkolenia, o których mowa powyżej, są realizowane między innymi w środowisku Katedry Pedagogiki Muzyki UKW w Bydgoszczy. Należy do nich projekt edukacyjno-badawczy Muzopolis ${ }^{4}$, którego założenia nawiązują do praktycznego popularyzowania teorii uczenia się muzyki E.E. Gordona w środowisku zainteresowanych edukatorów muzyki. Projekt Muzopolis obejmuje praktyczne programy rozwoju kreatywności w myśleniu muzycznym dzieci w wieku żłobkowym, przedszkolnym i wczesnoszkolnym. Kształtowanie dziecięcych schematów wyobrażeniowych w muzyce jest typowe dla tego wieku i zarazemetapu rozwijania audiacji. Jednak to tworzenie i przetwarzanie modeli pojęć i symboli w muzyce jest celem właściwym, którego osiągnięcie w dalszych etapie rozwoju dziecka jest konieczne w aktywności twórczej i improwizacyjnej.

W dorobku studentów można odnotować wiele prób badawczych odwołujących się do aplikacyjności i generatywności wybranych elementów teorii uczenia się muzyki E.E. Gordona. Do alternatywnych programach wczesnego umuzykalniania należą badania studentów: B. Leman, J. Jesiotr, D. Piwko i M. Piaseckiej (Jesiotr 2014; Leman 2014; Piasecka 2014; Piwko 2014). Przeprowadzone badania nawiązywały do jakościowego opisu „pól semantycznych” w opisie podstawowych znaczeń dziecięcegoeksperymentowania z muzyką. Chodziło także o to, aby w świetle wyników obserwacji muzycznych działań rodziców i nauczycieli można było odnieść się też do znanych, utrwalanych i modyfikowanych przyzwyczajeń traktowanych tu -za P. Bourdieu czy J.C. Kaufmannem - jako schematy myślenia i zależne od nich schematy działań, które stały się, bądź niebawem staną się faktem (Kaufmann 2004, s. 164-165). Analiza tego wątku pozwalała dodatkowo zrozumieć motywy i możliwości/ograniczenia działań osób dorosłych w zakresie kreatywnego umuzykalniania dzieci.

${ }^{4}$ Projekt Muzopolis obejmuje cykl programów intensywnego umuzykalniania dzieci w oparciu o koncepcję oddziaływań wynikającą z teorii uczenia się muzyki E.E. Gordona. Projekt ten jest realizowany w Katedrze Pedagogiki Muzyki w Instytucie Pedagogiki UKW w Bydgoszczy we współpracy z Polskim Towarzystwem Edwina E. Gordona oraz Fundacją Kreatywnej Edukacji. 


\section{DIAGNOZA PREDYSPOZYCJI MUZYCZNYCH W PROCESIE PROJEKTOWANIA DYDAKTYCZNEGO}

Nauczyciele często wykazują zainteresowanie zagadnieniami pomiaru i oceny zdolności i osiągnięć muzycznych w różnych warunkach sytuacyjnych, głównie odnosząc się do rzeczywistego potencjału predyspozycji dziecka do nauki muzyki. Istotnie ta problematyka (diagnoza zdolności specjalnych i preferencji) jest najbardziej eksponowanym przez praktyków edukacji dziecka wątkiem w refleksji o determinantach pomyślnego uczenia się dzieci. Stąd potrzeba aktualizacji wiedzy w tym zakresie jest rzeczywiście istotna (Weiner 2007; 2011, s. 19-32; Bonna 2016, s. 61-67). Przykłady egzemplifikujące tę potrzebę i możliwość zastosowania przez nauczycieli edukacji muzycznej konkretnych narzędzi pomiaru predyspozycji dziecka z wykorzystaniem aparatury E.E. Gordona można odnaleźć w pracach wielu badaczy (Bonna 2013, s. 76-85; zob. też: 2016, s. 217-223). Możliwość przeprowadzenia dobrych, w zasadzie prostych w instrukcji testów muzycznych przez nauczycieli muzyki prawie zawsze odnosi się do kształcenia muzycznego, tak formalnego, jak nieformalnego, ogólnokształcącego i specjalistycznego w szkolnictwie muzycznym. Zapisy piśmiennicze przeprowadzonych w ostatnich latach prób badawczych i aplikacji testów E.E. Gordona w warunkach codziennej praktyki nauczycieli muzyki są od początku powszechnie dostępne środowiskom zainteresowanych praktyków, a problematyka kształcenia nauczycieli edukacji muzycznej silnie, idąc za myślą M. Kołodziejskiego, nawiązuje do potrzeby rozwijania ich badawczych kompetencji (Kołodziejski2012, s. 357-372; Trzos 2014a).

Analizę kryteriów aplikacyjności teorii E.E. Gordona w zakresie diagnozy i wyjaśniania predyspozycji dziecka do rozwoju audiacjipodjęto w odrębnych badaniach I. Wojciechowskiej, A. Szatkowskiej oraz M. Pamuły. Wyniki badań ilościowego rozkładu preferencji i ich roli w edukacji muzycznej pozwalają odnieść się do wskazanego przez E.A. Zwolińską kryterium oceny aplikacyjności i generatywności teorii E.E. Gordona, tj. kryterium przydatności praktycznej, według którego poznawany jest rzeczywisty byt i stopień aplikacyjności teorii (Zwolińska 2011, s. 84). Wyniki badania preferencji barwy instrumentalnej wybranej próbki uczniów klas trzecich w szkolnictwie ogólnokształcącym przedstawia tabela 1 (Szatkowska 2013). 
Tabela 1. Wyniki ogólne testu ITPT E.E. Gordona wśród uczniów klasy III ogólnokształcącej szkoły podstawowej

\begin{tabular}{|c|c|c|c|c|c|c|c|}
\hline \multirow{3}{*}{$\begin{array}{c}\mathrm{Nr} \\
\text { ucznia }\end{array}$} & \multicolumn{7}{|c|}{ Grupa instrumentów muzycznych (wg ITPT E.E. Gordona) } \\
\hline & \multicolumn{7}{|c|}{ grupa } \\
\hline & I & II & III & IV & $\mathrm{V}$ & $\mathrm{VI}$ & VII \\
\hline 1 & $\mathrm{~W}$ & $\mathrm{~W}$ & $\mathrm{U}$ & $\mathrm{N}$ & $\mathrm{N}$ & $\mathrm{U}$ & $\mathrm{B}$ \\
\hline 2 & B & $\mathrm{W}$ & $\mathrm{W}$ & $\mathrm{U}$ & $\mathrm{B}$ & $\mathrm{U}$ & $\mathrm{B}$ \\
\hline 3 & $\mathrm{~N}$ & W & $\mathrm{W}$ & B & B & $\mathrm{U}$ & $\mathrm{N}$ \\
\hline 4 & $\mathrm{~N}$ & $\mathrm{~W}$ & $\mathrm{U}$ & W & B & $\mathrm{N}$ & B \\
\hline 5 & $\mathrm{~W}$ & $\mathrm{~W}$ & $\mathrm{U}$ & $\mathrm{N}$ & $\mathrm{B}$ & $\mathrm{N}$ & $\mathrm{B}$ \\
\hline 6 & $\mathrm{~N}$ & B & B & $\mathrm{U}$ & $\mathrm{U}$ & $\mathrm{W}$ & $\mathrm{W}$ \\
\hline 7 & $\mathrm{U}$ & $\mathrm{U}$ & B & $\mathrm{U}$ & $\mathrm{U}$ & $\mathrm{U}$ & B \\
\hline 8 & $\mathrm{~W}$ & $\mathrm{~N}$ & $\mathrm{~W}$ & $\mathrm{~N}$ & $\mathrm{~N}$ & $\mathrm{~N}$ & $\mathrm{~B}$ \\
\hline 9 & $\mathrm{~W}$ & $\mathrm{U}$ & $\mathrm{W}$ & $\mathrm{U}$ & $\mathrm{B}$ & $\mathrm{N}$ & $\mathrm{B}$ \\
\hline 10 & $\mathrm{U}$ & W & W & $\mathrm{B}$ & $\mathrm{U}$ & $\mathrm{U}$ & B \\
\hline 11 & $\mathrm{~B}$ & $\mathrm{~W}$ & $\mathrm{~N}$ & $\mathrm{U}$ & $\mathrm{B}$ & $\mathrm{U}$ & $\mathrm{W}$ \\
\hline 12 & B & B & $\mathrm{U}$ & B & $\mathrm{W}$ & $\mathrm{U}$ & $\mathrm{U}$ \\
\hline 13 & $\mathrm{U}$ & $\mathrm{W}$ & $\mathrm{U}$ & B & $\mathrm{B}$ & $\mathrm{U}$ & $\mathrm{N}$ \\
\hline 14 & $\mathrm{U}$ & $\mathrm{U}$ & W & $\mathrm{U}$ & $\mathrm{N}$ & $\mathrm{N}$ & B \\
\hline 15 & B & $\mathrm{W}$ & $\mathrm{W}$ & B & $\mathrm{N}$ & $\mathrm{N}$ & $\mathrm{W}$ \\
\hline 16 & $\mathrm{~W}$ & $\mathrm{~N}$ & $\mathrm{U}$ & $\mathrm{N}$ & $\mathrm{W}$ & $\mathrm{N}$ & $\mathrm{B}$ \\
\hline 17 & $\mathrm{~W}$ & $\mathrm{U}$ & $\mathrm{W}$ & B & B & B & $\mathrm{U}$ \\
\hline 18 & $\mathrm{U}$ & $\mathrm{U}$ & $\mathrm{U}$ & $\mathrm{U}$ & $\mathrm{N}$ & $\mathrm{U}$ & B \\
\hline
\end{tabular}

Oznaczenia: B - brak preferencji, $\mathrm{N}$ - niski poziom preferowania barwy, $\mathrm{U}$ - poziom umiarkowany preferowania barwy, $\mathrm{W}$ - wysoki poziom preferowania barwy (proponowany instrument do nauki gry)

Źródło: Szatkowska 2013, s. 45-51.

W świetle wyników testowego badania preferencji na próbce polskich uczniów klasy III ogólnokształcącej szkoły podstawowej można było dostrzec, że w rozkładzie preferowanych przez uczniów barw są barwy wysoko i umiarkowanie preferowane. Można również dostrzec, że dzieci w wieku 10 lat mogą preferować barwę więcej niż jednego instrumentu, a w nielicznych przypadkach dotyczy to nawet trzech instrumentów. Takie uogólnienia wcześniej wyprowadził także E.E. Gordon, zauważając, że w przybliżeniu czterech na pięciu badanych Testem ITPT ma jedną lub więcej preferowanych barw, a także jedną lub więcej barw, których ewidentnie nie lubi (Gordon 1984, s. 16-23). Ten aspekt, tj. braku preferencji, udało się poddać analizie w badaniach A. Szatkowskiej, dostrzegając, że każdy z badanych uczniów potrafi wyraźnie wskazać te instrumentu muzyczne, których barwy nie preferuje. To bardzo ważny kierunek refleksji z uwagi na fakt, iż instrumenty te mogą wywoływać u uczniów niechęć do nauki (zob. też: Trzos 2009, s. 74-76). 
Podobnie badania sondażowe I. Wojciechowskiej na próbie blisko 100 uczestników pięciu orkiestr dętych w nieformalnym ruchu muzycznym wybranych gmin województwa kujawsko-pomorskiego pozwoliły dostrzec podobieństwo sytuacji, iż większość uczniów potrafi określić także zdecydowanie wysokie/niskie preferencje w tym zakresie. Uczestnicy badanych pięciu orkiestr tworzyli projekt MUZA, który stał się terenem badań. W badaniach I. Wojciechowskiej podjęto zauważone przez P.A. Trzosa podobieństwo w tym zakresie pomiędzy ilościowym rozkładem preferencji dziewcząt i chłopców (Trzos 2009, s. 74-78), a także sprawdzono jakościowy rozkład profilu preferencji właśnie ze względu na płeć badanych. Jak wynika z badań I. Wojciechowskiej, najbardziej preferowaną barwą instrumentu wśród dziewcząt jest barwa saksofonu, klarnetu, a potem fletu poprzecznego. Do najmniej preferowanych instrumentów w tej grupie badanych należy tuba (Wojciechowska 2014, s. 50-53). W grupie chłopców najbardziej preferowaną barwą instrumentu okazała się także barwa saksofonu, a najmniej barwa fletu. Poznanie indywidualnych predyspozycji uczniów w tym zakresie jest ważne, bowiem powinno sugerować możliwości dzieci i kierunek optymalizowania warunków ich aktywności (od)twórczego wykonawstwa muzycznego. Eksponowana przez E.E. Gordona problematyka badania preferencji dziecka w tym zakresie okazuje się bardzo ważna. Aby wzbudzać wewnętrzną motywację dziecka do nauki muzyki warto bowiem analizować jego indywidualne usposobienie w tym zakresie. Wyniki studenckich badań potwierdzają doniesienia E.E. Gordona, które sugerują, że taka analiza jest możliwa jeszcze przed podjęciem fizycznego kontaktu $z$ instrumentem w szkole, a większość rozpoczynających kształcenie muzyczne uczniów już potrafi wyraźnie wypowiedzieć się w tym zakresie (Gordon 1984, s. 13-26; Trzos 2009, s. 77-78; Bonna 2013, s. 81-84).

Analizowano także doświadczenia nauczycieli wczesnej edukacji muzycznej w kontekście ich przygotowania i zainteresowania możliwością stosowania podobnych narzędzi pomiaru w praktyce. Badania w tym zakresie nawiązywały do wniosków polskich badaczy (zob. Bonna 2013, s. 76-81) i wynikały z pytań badawczych o doświadczenia nauczycieli w zadaniach pomiaru i oceny zdolności muzycznych uczniów. Sprawdzanie możliwości rozwiązywania problemów diagnozy muzycznego potencjału dziecka wymagało odniesienia się do przynajmniej dwóch kwestii. Pierwszą z nich jest koncentrowanie się na refleksji nauczycieli dotyczącej ich wiedzy osobistej w podejściu do kontaktu ze sztuką i twórczością muzyczną. Druga kwestia analizy tego wątku badań dotyczyła opisywanych przez badanych nauczycieli związków pomiędzy potocznymopisem zdolności muzycznych a subiektywną ocenąpotencjału twórczego dziecka w nauce muzyki. Doniesienia E.E. Gordona (1999, s. 184; Bonna 2016) wydają się w tym konkretnym nakreśleniu pola problemowego ważną inspiracją do dalszych badań. Okazuje się, że większość 
badanych nauczycieli dość pobieżnie i ogólnikowo opisuje swoje doświadczenia w tym zakresie (Pamuła 2013). Badania M. Pamuły pozwoliły też dostrzec potrzebę autoewaluacji wiedzy nauczyciela i jego stosunku do nowatorstwa strategii, programów i technik oceny potencjału ucznia wybitnie zdolnego.

\section{RUCH KREATYWNY - NOWE INSPIRACJE}

Maciej Kołodziejski zwrócił już uwagę na koncepcję rozwoju ruchu kreatywnego J.Feierabenda. Zwrócił też uwagę, iż implikowane w jego pracach labanowskie ujęcie ruchu podkreśla znaczenie zadań rozwoju kreatywności. Zauważa (Kołodziejski 2014, s. 158), iż „zasadniczym celem staje się angażowanie dzieci w zróżnicowane odśrodkowe działania kreatywne z użyciem ruchu w przestrzeni (z muzyką lub bez muzyki)". Choć są to zupełnie odrębne - od Gordonowskiej - koncepcje oddziaływania muzyczno-edukacyjnego, to wyraźnie widać, iż nie chodzi w nich wyłącznie o estetyzację muzycznej ekspresji dziecka, a analizę procesu ruchu ciągłego zorientowanego na kreatywność, twórczość i ostatecznie improwizację.Edwin E. Gordon zwraca uwagę na konieczność koncentrowania się w tym na czterech pojęciach, tj. przepływie, ciężarze, przestrzeni i czasie, a w odniesieniu do nich rozwijaniu umiejętności kreatywnego myślenia w muzyce. Rozwijanie myślenia muzycznego poprzez konkretne ruchowe działania wymaga aktywności umysłu i ciała w zakresie precyzji, uwagi, intencji i decyzji. W tych intelektualnych wysiłkach generowane i przetwarzane informacje pochodzą z odpowiedzi na pytania typu: gdzie? jak? co? kiedy? (Zwolińska 2012, s. 320-321). Szczególnie interesująca w podejmowaniu nowych problemów badań nad kreatywnością ruchu w muzyce jest analiza możliwości stymulowania charakterystycznych wzorów opartych na podobnych ustaleniach Rudolfa Labana (Zwolińska 2012, s. 328-329). Wzory te wiążą się z doświadczaniem emocji w ruchu, zwłaszcza w typie improwizacji, i zawierają się w kategoriach wynikających z „niekompletnych wymiarów działan””:

- akcja - ukryty przepływ (kombinacja: przestrzeni i czasu),

- przewidywanie działania - ukryty ciężar (kombinacja: przestrzeni i czasu),

- urok w ukierunkowanym działaniu - ukryty czas (kombinacja: przepływu i ciężaru),

- pasja działania - ukryta przestrzeń (kombinacja: przepływu i ciężaru).

Rudolf Laban, co zauważyła Ewa Zwolińska, zachęcał do wyostrzonego obserwowania sytuacji w powyższych momentach i sugerował budzenie świadomego posługiwania się niewiedzą $\mathrm{w}$ celu poszukiwania nowych modeli ruchów, które pozwoliłby na kreowanie nowej, upodmiotowionej, kultury tańca (Zwolińska 2012, s. 329). Bezpośrednie i aktywne doświadczanie tempa, metrum, dynamiki, artyku- 
lacji, tonalności, winno uwzględniać aktywność połączoną właśnie z ruchem. Ruch bowiem, na tym etapie edukacji dziecka, jest odpowiedzią na naturalną gotowość dziecka do spontanicznej ekspresji muzycznej (s. 296). Pisało o tym wielu badaczy, podkreślając właśnie kreatywny walor oddziaływań. Ruch kreatywny z muzyką ma postać ciągłą, a optymalne ćwiczenia w tym zakresie mają charakter rozwojowy i odbywają się przez ruchowe ilustracje treści muzycznej. Podłożem jest cel zorientowany na rozwijanie kreatywności jako cechy twórczego poziomu wnioskowania w muzyce. Stąd, jak zauważył M. Kołodziejski (2014, s. 155), propedeutykę proponowanych ćwiczeń dziecięcych stanowią zadania kierowane i improwizowane w odniesieniu do „dźwięku centralnego" w tonalności i metrum. Ten aspekt wnosi wiele inspiracji w kierunek projektowania sytuacji dydaktycznych we wczesnoszkolnej edukacji muzycznej. Wymaga to jednak dalszych i pogłębionych badań.

\section{PODSUMOWANIE}

Umiejętność audiowania umożliwia przetwarzanie treści muzycznej nie tylko na etapie różnicowania (subiektywnych i obiektywnych znaczeń w muzyce), ale przede wszystkim na etapie wnioskowania, które realizuje się poprzez uogólnianie, dialogowanie i przetwarzanie symboli teoretycznych. W tych trzech ostatnich dyspozycjach eksponowana jest umiejętność kreowania konkretnych standardów estetyzacji. Tworzenie i improwizowanie jest tego szczytową formą, gdzieaudiujący umysł może organizować i przetwarzać spostrzeżenia na wiele sposobów, zwłaszcza w rzeczywistości nieznanej muzyki. W tym wyraża się istota rozwoju kreatywnego myślenia w muzyce w oparciu o jej audiację. Nie chodzi zatem o wyłącznie emocjonalny walor kontaktu z muzyką. Coraz częściej takie postrzeganie aktywnego uczestnictwa w kulturze muzycznej okazuje się niewystarczające. Wnioski skłaniają do kolejnego przemyślenia następujących kwestii:

- Jakie aspekty poznania muzycznego mogą dodatkowo wspierać kreatywność dziecka w muzyce? Jaka jest rola analizy: komunikacji dziecko - dorosły za pomocą języka muzycznego, reinterpretacji znaczeń intersubiektywnych wzorów rodzimej kultury muzycznej dziecka, jego wyobraźni muzycznej czy rozwoju świadomości brzmieniowej w muzyce?

- Jakie są źródła kreatywności muzycznej dziecka, które powinny być stale monitorowane $\mathrm{w}$,strefie najbliższego rozwoju”?

- Jaka jest mapa zmiennych rozwoju kreatywnego myślenia muzycznego, jeśli przyjmiemy, iż nie „kontrast” znaczeń a „płynność” ich przetwarza-

\footnotetext{
${ }^{5}$ Nawiązuję do namysłu L.S Wygotskiego (Filipiak, Lemańska-Lewandowska 2015).
} 
nia odgrywa istotną rolę w procesie muzycznej decyzyjności (Zwolińska 2016, s. 136; za: Reber, Schwarz, Winkielman 2004, s. 364-382; Gazzaniga 2011, s. 235)?

Spośród wielu spostrzeżeń warto wyeksponować wnioski, iż:

- aktywność badawcza studentów pedagogiki wczesnoszkolnej wymaga uwzględnienia powyższych kwestii, zwłaszcza w obszarze analizy pola kreatywności dziecięcej w przestrzeni edukacji muzycznej,

- diagnoza kompetencji dorosłych (nauczycieli i rodziców) powinna uwzględniać aspekty znajomości (przynajmniej kluczowych problemów) istoty rozwoju myślenia muzycznego i jej audiacyjnego kontekstu,

- prace badawcze studentów mogą być istotnym czynnikiem stymulującym autorefleksję przyszłych nauczycieli nad znaczeniem oddziaływania muzyczno-rozwojowego na etapie wczesnoszkolnej edukacji,

- zainteresowanie dziecka muzyką jest kluczowe, ale w praktyce powinno się eksponować twórczo-improwizacyjny typ audiowania. Jest to możliwe choćby poprzez angażowanie całego ciała dziecka w kreatywnym ruchu z muzyką, muzyczną synektykę, zadania modulacji i transpozycji realizowanego repetuaru, improwizowanie, zwłaszcza w oparciu o solfeż (ruchowy, tonalny i rytmiczny), oraz poprzez asymilowanie i antycypowanie w pamięci konkretnych pasaży czy wręcz klasterów ${ }^{6}$ harmonicznych.

\section{LITERATURA}

Bee R.F.,1998, Feedback. Warszawa, Wyd. PETIT.

Bonna B., 2006, Rodzina i przedszkole w kształtowaniu umiejętności muzycznych dzieci. Zastosowanie koncepcji Edwina E. Gordona. Bydgoszcz, Wyd. AB.

Bonna B., 2013, Research on the Application of E.E. Gordon's Theory of Music Learning in the Music Education in Poland. „Culture and Education”, 6 (99), 66-87.

Bonna B., 2016, Zdolności i kompetencje muzyczne uczniów w młodszym wieku szkolnym. Bydgoszcz, Wyd. UKW.

Filipiak E., Lemańska-Lewandowska E., 2015, Możliwości rozwijania myślenia i uczenia się dzieci poprzezstawianie zadań rozwojowych. W: E. Filipiak (red.), Nauczanie rozwijające we wczesnej edukacji wedlug Lwa S. Wygotskiego. Od teorii do zmiany w praktyce. Projekt Akademickie Centrum Kreatywności. Bydgoszcz, Wyd. UKW, 39-65.

${ }^{6}$ Mowa o możliwościach jakie daje kombinacja tonalna z zastosowaniem kryteriów multitonalności i politonalności w muzyce. To, trzeba przyznać, jest trudnym wyzwaniem i z pewnością wymaga dłuższej perspektywy czasowej przygotowania dydaktycznego. 
Filipiak E., Lemańska-Lewandowska E., Szymczak J., 2015, Feedback i jego rola $w$ tworzeniu krytycznej przestrzeni $i$ warunków dla prowadzenia konwersacji ułatwiającej nauczycielom rozumienie własnej praktyki edukacyjnej. W: E. Filipiak, E. Lemańska-Lewandowska (red.), Model nauczania rozwijającego we wczesnej edukacji według Lwa S. Wygotskiego. Gotowość studentów i nauczycieli. Możliwość aplikacji. Raport tematyczny z realziacji projektu Akademickie Centrum Kreatywności. Bydgoszcz,Wyd. UKW, 167-184.

Fish D., 1996, Kształcenie poprzez praktykę [oryg. Learning Through Practice in Initial Teacher Training], tłum. D. Klus-Stańska, H. Mizerek. Warszawa, CODN.

Gazzaniga M., 2011, Istota człowieczeństwa. Co sprawia, że jesteśmy wyjątkowi. Sopot, Wyd. Smak Słowa.

Gordon E.E., 1984, Manual for the Instrument Timbre Preference Test, GIA. Chicago, Publication, Inc. 7404 So. Mason. Ave IL 50538..

Gordon E.E., 1999, Sekwencje uczenia się w muzyce. Umiejętności, zawartość i motywy. Bydgoszcz, Wyd. WSP.

Gordon E.E., 2016, Teoria uczenia się muzyki. Niemowlęta i małe dzieci. Gdańsk, Wyd. Harmonia Universalis.

Gordon E.E., Woods D., 1999, Zanurz się w program nauczania muzyki. Bydgoszcz, Wyd. UKW.

Gordon E.E., Bolton B.M., Hicks W.K., Taggart C.C., 1993, The Early Childhood Music Curriculum. Experimental Songs and Chants without Words. Book one. Chicago, GIA Publications, Inc.

Grusiewicz M., 2015, Wkład czasopisma „Wychowanie Muzyczne w Szkole” w rozwój praktyki i teorii powszechnej edukacji muzycznej w Polsce. Lublin, Wyd. UMCS. Kamza A., 2014, Rozwój dziecka. Wczesny wiek szkolny, w: A.I. Brzezińska (red.), Niezbednik Dobrego Nauczyciela, Seria I, t. 3. Warszawa, Instytut Badań Edukacyjnych Kaufmann J.C., 2004, Ego. Socjologia jednostki. Inna wizja człowieka i konstrukcji podmiotu, przeł. K. Wakar. Warszwa, Oficyna Naukowa.

Kojs R., 2000, Dziecięca muzyka eksperymentalna, w: Dymara B. (red.), Dziecko $w$ świecie muzyki. Kraków.

Kołodziejski M., 2012, Music Teacher as a Researcher of Educational Process, "Mūzikaszinātnešodien: pāstavīgaisunmainīgais. Zinātniskorakstukrājums", t. 4. Daugavpils Universitātes Akadēmiskiaisapgāds „Saule”, 357-372.

Kołodziejski M., Trzos P.A., 2013, Środowiskowy wymiar uczenia się muzyki w kontekście rozwoju audiacji, „Studia Pedagogiczne. Problemy społeczne, edukacyjne i artystyczne", t. 22, 165-181.

Kołodziejski M., 2014, Koncepcja ruchu kreatywnego Johna Feierabenda w edukacji przedszkolnej i wczesnoszkolnej. W: M. Kołodziejski (red.), Kreatywność w edukacji muzycznej. Pułtusk, Wyd. AH, 141-161. 
Konaszkiewicz Z., 2012, U podstaw pedagogiki muzycznej w perspektywie przeszłości i przyszłości, w: A. Michalski (red.), Tożsamość pedagogiki muzyki. Seria: Pedagogika muzyki. Cechy - aksjologia - systematyka, t. 1. Gdańsk, Wyd. Athenae Gedanenses, 47-67.

Leman B., 2014, Możliwości intensywnego umuzykalniania dzieci na przykładzie projektu edukacyjnego „Muzopolis”. Niepublikowana praca licencjacka, złożona i obroniona w Katedrze Pedagogiki Muzyki Instytutu Pedagogiki w Uniwersytecie Kazimierza Wielkiego. Bydgoszcz.

Murawska B., 2014, Edukacja wczesnoszkolna, w: A.I. Brzezińska (red.), Niezbednik Dobrego Nauczyciela, Seria III, t. 3. Warszawa, Instytut Badań Edukacyjnych.

Niśkiewicz K., 2013, Realizacja elementów muzyki w zakresie melodii i rytmu przez dzieci w klasie trzeciej szkoły podstawowej. Niepublikowana praca licencjacka, złożona i obroniona w Katedrze Pedagogiki Muzyki Instytutu Pedagogiki w Uniwersytecie Kazimierza Wielkiego. Bydgoszcz.

Piasecka M., 2014, Postrzeganie procesów audiacji wstępnej w opiniach studentów o rodziców (na przykładzie projektu edukacyjno-badawczego „Muzopolis”). Niepublikowana praca licencjacka, złożona i obroniona w Katedrze Pedagogiki Muzyki Instytutu Pedagogiki w Uniwersytecie Kazimierza Wielkiego. Bydgoszcz.

Piwko D., 2014, Edukacyjne zaangażowanie rodziców w aktywne formy umuzykalniania dzieci na przykładzie projektu „Muzopolis”. Niepublikowana praca licencjacka, złożona i obroniona w Katedrze Pedagogiki Muzyki Instytutu Pedagogiki w Uniwersytecie Kazimierza Wielkiego, Bydgoszcz.

Reber R., Schwarz N., Winkielman P., 2004, Processing fluency and aesthetic pleasure: Is beauty in the perceiver's processing ezperience? „Personality and Social Psychology Review" 8, 364-382.

Reber A.S., 1985, The dictionary of psychology. London, PenguinBooks.

Szatkowska A., 2013, Rozwijanie preferencji muzycznych dzieci klasy trzeciej w ogólnokształcącej szkole podstawowej. Niepublikowana praca licencjacka, złożona i obroniona w Katedrze Pedagogiki Muzyki Instytutu Pedagogiki w Uniwersytecie Kazimierza Wielkiego, Bydgoszcz.

Trzos P.A., 2009, Preferencje barwy dźwięku i zdolności muzyczne w nauce gry na instrumencie dętym. Badania edukacyjne nad adaptacja teorii uczenia się muzyki E.E. Gordona, Poznań-Kalisz-Konin, Wyd. UAM PWSZ.

Trzos P.A., 2012, Codzienność we wczesnej edukacji muzycznej. Bydgoszcz, Wyd. UKW. Trzos P.A., 2014a, Dziecięce uczenie się muzyki w badawczym oglądzie studenta pedagogiki - o efektywności praktyki pedagogicznej, W: J. Grzesiak (red.), Profesjonalne praktyki - Profesjonalni nauczyciele. Konin, Wyd. PWSZ.

Trzos P.A., 2014b, Kierowanie muzyczne we wczesnej edukacji dziecka. W: A. Klim-Klimaszewska, E. Jagiełło (red.), Edukacja ku przyszłości. Wyzwania i zaniechania w wy- 
chowaniu przedszkolnym i kształceniu wczesnoszkolnym. Siedlce, Wyd. Siedleckie Towarzystwo Naukowe.

Trzos P.A., 2016, Wspólnotowy kontekst rozwoju dziecięcego audiowania $w$ rodzinie.

W: M. Nawrot-Borowska, D. Zając (red.), Dziecko w perspektywie diachronicznej i synchronicznej. Bydgoszcz, Wyd. UKW, 69-88.

Waloszek D., 2008, Estetyka sytuacji edukacyjnych. W: Uchyła-Zroski J. (red.), Wartości $w$ muzyce. Studium monograficzne, t. 1. Katowice, Wyd. UŚ, 35-46.

Weiner A., 2007, Test Muzycznych Umiejętności Percepcyjnych. Podręcznik. Lublin, Wyd. UMCS.

Weiner A., 2010, Kompetencje muzyczne dzieci w młodszym wieku szkolnym. Determinanty, zależności, perspektywy rozwoju. Lublin, Wyd. UMCS.

WeinerA., 2011, Możliwości wykorzystania diagnostyki edukacyjnej w kształceniu muzycznym, w: W.A. Sacher, A. Weiner (red.), Badania naukowe nad edukacja artystyczna i kulturową. Bielsko-Biała, WSA, 19-32.

Weiner A., 2013, Od scjentyzmu w stronę humanistyki - metoda projektów w kształceniu studentów edukacji muzycznej. W: R. Gozdecka, A. Weiner (red.), Profesjonalizm w edukacji muzycznej. Propozycje dla zmieniającej się szkoły. Lublin, Wyd. UMCS, 31-46. Zwolińska E.A., 2011, Audiacja. Studium teorii uczenia się muzyki Edwina E. Gordona. Bydgoszcz, Wyd. UKW.

Zwolińska E.A., 2012, Kształcenie nauczycieli według teorii uczenia się muzyki Edwina E. Gordona. Bydgoszcz, Wyd. UKW.

Zwolińska E.A., 2014, Sposoby audiacji o myśleniu muzycznym. Bydgoszcz, Wyd. UKW. Zwolińska E.A., 2016, Sens umuzykalniania. O celowości edukacji muzycznej. Bydgoszcz, Wyd. UKW.

\title{
CREATIVITY IN MUSIC THINKING AS A SUBJECT OF MUSIC AND EDUCATIONAL RESEARCH LED BY STUDENTS OF EARLY SCHOOL EDUCATION
}

\begin{abstract}
The text highlights selected research themes explored by students of early school education, concerning the conditions for creative thinking development in music. The creativity is analysed in connection with audiation development, which in the light of the Gordon music learning theory is described as one of the most important paths in implementation of the music education process. It applies to various forms of music activity and forms part of the task of preparing children to active participation in music culture. The sole focus of the reflection on pupils in early school age results from the belief that in that developmental period a dynamic program for stimulation of thinking in music is most important.
\end{abstract}

Key words: audiation, music education, creative music education, child 